\title{
INAPPROPRIATE REQUESTS FOR TUMOR MARKERS IN PATIENTS AGED $5 O$ YEARS AND OLDER: LESSONS NOT LEARNED
}

\author{
Solicitação inapropriada de marcadores tumorais em \\ pacientes com 50 anos ou mais: lições não aprendidas
}

\author{
Valter Paz Nascimento-Júniora (i), Einstein Francisco Camargos ${ }^{\mathrm{a}}$ (1)
}

OBJECTIVE: To investigate, within a private health insurance, the ordering frequency and the costs related to inappropriate tumor markers test orders. METHODS: This study analyzed data regarding tumor markers requests within a private health insurance between 2010 and 2017. Patients included in this analysis were $\geq 50$ years old, had available medical records, and had at least 1 tumor markers tested within the study period. Tests were considered inappropriate when tumor markers were used in screening for neoplasms, ie, when there was no previous diagnosis. We evaluated data regarding age, sex, the ordering physician's medical specialty, and test costs. RESULTS: Between 2010 and 2017, 1112 tumor markers tests were performed and increased from 52 to 262 per year. Our sample consisted mostly of women (69.50\%) with a mean age of 59.40 (SD 8.20 ) years. Most orders were inappropriate (87.80\%) and represented $79.40 \%$ of all expenses with tumor markers tests. Cardiology professionals were the medical specialty that requested the most tumor markers tests (23.90\%), followed by internal medicine specialists (22.70\%) and gynecologists (19.20\%). CONCLUSIONS: We observed a high percentage of inappropriate test orders in the study period, resulting in elevated costs. Studies of this nature deserve the attention of health care managers, and interventions should be performed in order to reduce the inappropriate use of tumor markers tests in clinical practice.

KEYWORDS: biomarkers; mass screening; medical examination; medical overuse.

OBJETIVO: investigar no âmbito de um plano de saúde privado a frequência de solicitação e os custos relacionados à solicitação inapropriada de marcadores tumorais. METODOLOGIA: Utilizou-se a base de dados de um plano de saúde privado entre os anos de 2010 a 2017. Foram incluídos na pesquisa, sujeitos com idade $\geq 50$ anos, que apresentavam prontuários médicos acessíveis e que havia realizado a dosagem de algum marcadores tumorais no período. Considerou-se como "exame inapropriado" quando o marcador tumoral foi utilizado como rastreio de neoplasia, ou seja, quando não havia o diagnóstico prévio. Foram avaliados os dados referentes à idade, sexo, especialidade do médico solicitante e informações sobre os custos desses exames. RESULTADOS: Foram realizados um total 1.112 testes no período, representando um aumento de 52 para 262 exames/ano. A amostra foi composta na maioria pelo sexo feminino (69,50\%), com média de idade de 59,40 \pm 8,20 anos. A maioria das solicitações foram inapropriadas (87,80\%). Notou-se que a solicitação desses exames, impactaram cerca de 79,40\% dos gastos totais do plano de saúde com marcadores tumorais. Os cardiologistas foram a especialidade que mais solicitaram marcadores tumorais em 23,90\% das ocasiões, seguidos pelos especialistas em clínica médica (22,70\%) e ginecologistas (19,20\%). CONCLUSÕES: Observamos um alto percentual de pedidos de exames inadequados no período do estudo, resultando em custos elevados. Estudos dessa natureza merecem a atenção dos gestores de saúde e intervenções devem ser realizadas a fim de reduzir o uso inadequado de testes de marcador tumoral na prática clínica.

PALAVRAS-CHAVE: biomarcadores; programas de rastreamento; exames médicos; sobremedicalização.

aUniversidade de Brasília - Brasília (DF), Brazil.

Correspondence data

Einstein Francisco Camargos - Departamento de Medicina Clínica, Ambulatório de Geriatria, Hospital Universitário de Brasília - Setor de Grandes Áreas Norte, 605 - Avenida L2 Norte - Asa Norte - CEP: 70840-901 - Brasília (DF), Brazil. E-mail: einsteinfc@gmail.com

Received on: 09/18/2020. Accepted on: 11/28/2020

https://doi.org/10.5327/Z2447-212320212000113 


\section{INTRODUCTION}

The technological advances of medicine in recent years are undeniable, especially regarding new diagnostic tests and laboratory prognoses. However, along with this development, new technologies have also brought substantial increases in financial costs to health care services, thus burdening patients and governments, particularly in countries with limited financial resources. The inappropriate use of new health care technologies has grown in many countries, and despite attempts by several publications and guidelines to standardize their use, impactful statistics are shown in the literature regarding the excessive use of these technologies. ${ }^{1}$ Beyond financial costs, other possible damages are associated with the inappropriate use of diagnostic tests, especially the risk of excessive diagnostic test requests and unnecessary treatments. ${ }^{2}$ The definition of inappropriate or unsuitable test is broad and can be interpreted in many ways. According to Zhi et al., an inappropriate test is one which is requested without a clear indication of a diagnostic hypothesis for a specific case. ${ }^{3}$ Additionally, an adequate clinical indication for testing should also consider sensitivity, specificity, and predictive value studies for the diseases it aims to diagnose; these are generally established by guidelines published by governments, institutes, or medical specialties such as the United States Preventive Services Task Force (USPSTF). However, unlike pharmaceutical clinical studies, studies on the sensitivity and specificity of diagnostic tests are not commonly found in the literature.

In this context, tumor markers (TMs) have been frequently used in clinical practice as screening tests for people aged 50 years and older. ${ }^{4} \mathrm{TM}$ s include various substances such as cell surface antigens, cytoplasmic proteins, enzymes, hormones, oncofetal antigens, receptors, and oncogenes and their products. According to Sharma, the 3 most important characteristics of an ideal TM are high specificity for a certain type of tumor, reasonable lead-time over the clinical diagnosis, and high sensitivity to avoid false-positive results. ${ }^{5,6}$ Unfortunately, these characteristics are relatively hard to come by in clinical practice, which has led to a general recommendation of not ordering TM tests in routine screening procedures in asymptomatic patients. ${ }^{7-9}$

Considering that the financial costs of health care services have grown significantly in recent years, optimizing expenses is important. Conversely, various studies have indicated a high percentage of inadequate orders for TM tests. In Greece, Ntaios et al. identified only $10 \%$ of correctly requested TM tests among 10921 tests, notably cancer antigen 125 (CA 125), alpha-fetoprotein (AFP), cancer antigen 19-9 (CA 19-9), cytokeratin 19 fragment (CYFRA 21-1), and neuron-specific enolase (NSE). ${ }^{10}$
Studies evaluating the inadequate request of TM tests are scarce in Brazil. This study investigated, within a private health insurance, the ordering frequency and the costs related to inadequate orders of TM tests such as CA 125, carcinoembryonic antigen (CEA), CA 19-9, cancer antigen 15-3 (CA 15-3), cancer antigen 72-4 (CA 72-4), and cancer antigen 27-29 (CA 27-29).

\section{METHODS}

This retrospective study was performed within a non-profit, private employer-sponsored health insurance. This health insurance is managed by a federal public institution located in Brasília, Federal District, Brazil. Its financial resources are mostly provided by the government, whereas a smaller fraction is funded by the users (approximately 20\%). This health insurance covers an annual average of 5979 users, including current or retired employees and their dependents.

The study population consisted of all the individuals who performed complementary blood tests through their health insurance plans between 2010 and 2017. Only active employees (and not those retired or dependents) aged 50 years and older with accessible medical records were included. This age threshold was established in order to select patients who commonly undergo screening tests. The year 2012 was not analyzed due to data inconsistency, since there was a change in the management software that could result in possible methodological bias.

The "inappropriate tests" variable was considered present when no previous neoplasm diagnosis had been performed and at least one of the following TMs were present on the medical records: CA 125, CEA, CA 15-3, CA 72-4, CA 19-9, and CA 27-29; these were grouped under the "TM" variable. The criteria for this classification were established following recommendations by USPSTF, ${ }^{11-13}$ The Royal Australian College of General Practitioners (RACGP), ${ }^{14}$ and the American Society of Clinical Oncology (ASCO). ${ }^{15}$

Other variables analyzed in this study include age (completed years at the time of testing), sex (male/female), the ordering physician's medical specialty, and information on costs (individual test costs and user co-participation) as informed by the insurance manager. Values in reais (Brazilian currency, $\mathrm{R} \$$ ) were converted to US dollars considering the exchange rate in February 2020 (US\$1.00 = R \$4.06) ) $^{16,17}$.

It is reasonable to consider that all cancer diagnoses were recorded, since any sick leave, notification, or even early retirement due to cancer are reported on the patients' medical records. The medical records were reviewed by the study's designated physician.

All statistical analyses used SPSS v.25.0. Descriptive statistics were used in measures of position (mean, median, and 
standard deviation), and the $\chi^{2}$ test, Fisher's exact test, and binary logistic regression were performed as appropriate.

The study was approved by the Research Ethics Committee of the Medical School of the Universidade de Brasilia (CAAE 88696318.9.0000.5558).

\section{RESULTS}

Between 2010 and 2017, 1112 TM tests were ordered, and yearly orders increased from 52 to 262 . Our sample consisted mostly of women (69.50\%) with a mean age of 59.40 $(\mathrm{SD}, 8.20)$ years.

The analysis of medical records showed that $12.20 \%$ $(n=136)$ of tests were appropriately ordered (that is, were ordered after cancer diagnosis) and $87.80 \%(\mathrm{n}=976)$ were inappropriately ordered.

Of 136 orders considered appropriate, $80.90 \%$ were for female patients, with a mean age of 60.40 (SD, 7.40) years. The odds of adequate test ordering were associated with patient age (Odds Ratio [OR] = 1.08, 95\% [confidence interval] CI: $1.03-1.13)$ and female patients $(\mathrm{OR}=8.37,95 \% \mathrm{CI} 4.08-$ 17.17) $\left(\chi^{2}(2)=43.96 ; p<0.001\right.$, Nagelkerke $\left.R^{2}=0.27\right)$.

A progressive increase was observed in absolute and per capita numbers of inappropriate test orders over the years, from 48 test orders in 2010 (mean of 8.70 orders per 1000 registered users) to 227 orders in 2017, corresponding to 34.90 orders per 1000 registered users (Figure 1).

The total costs of TM tests in the study period were US\$156 452.60. Of these, US\$124222.91 (79.40\%) were spent on inappropriate orders, which increased from US\$ 3127.17 in 2010 to US\$26 776.83 in 2017. The mean cost of inappropriate tests was US\$16.81 (SD, US\$15.58) for the patient and US\$110.43 (SD, US\$91.16) for the government. Between 2010 and 2017, the mean cost of inappropriate test orders was US $\$ 2.90$ for every health insurance user (Table 1 ).

Regarding the medical specialty of ordering physicians, most were cardiologists (23.90\%), internal medicine specialists (22.70\%), obstetricians and gynecologists (19.20\%), and general practitioners (10.14\%). Although clinical oncologists were ranked seventh on this list, with only $5.60 \%$ of all orders, they presented the most adequate test orders in comparison with other specialties, with a statistically significant association. Data on test orders by medical specialty are shown in Table 2 .

\section{DISCUSSION}

In this study, performed within a private health insurance, we observed a significant and progressive increase in the number of inappropriate TM test orders without the appropriate cancer diagnosis and in contrast with what is recommended by scientific societies. We observed a substantially high rate of inappropriate requests (85.20\%), generating expenses that accounted for $79.40 \%$ of all expenses with TM tests.

Brazilian studies on this field are scarce. However, a high frequency of inappropriate test requests was also observed in other countries. In Greece, $90 \%$ of TM test orders were inappropriate. ${ }^{10}$ In Modena, Italy, a study reported that $62 \%$ of patients admitted to an internal medicine unit were ordered at

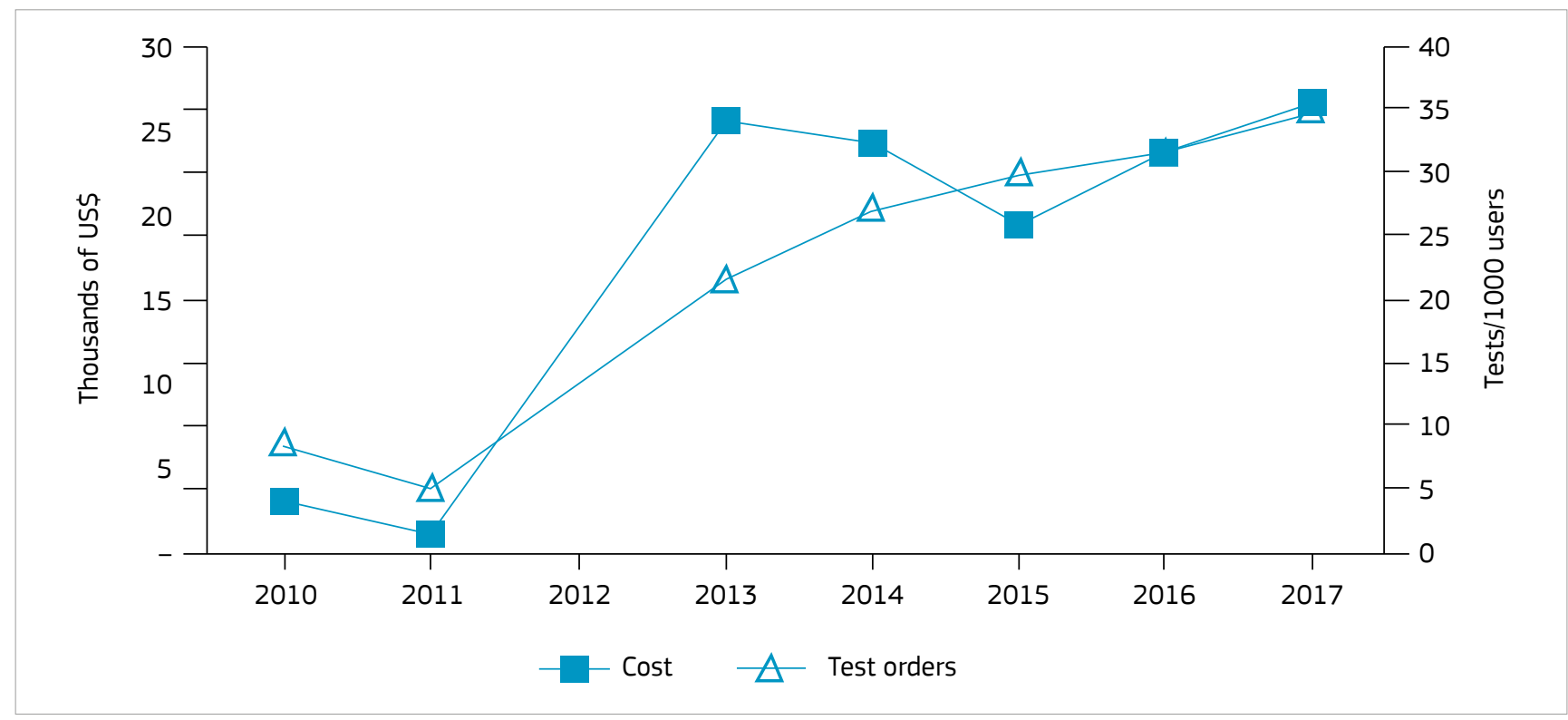

Figure 1. Number of inappropriate tumor marker requests per 1000 health insurance users between 2010 and 2017 and related costs. 
least one TM test. ${ }^{18}$ In Padua, less than 40\% of 23059 TM test orders within a university hospital were considered adequate. ${ }^{19}$ Another broad Italian study revealed an estimate of more than one request for biomarker testing for every 5 people, which did not correspond to the cancer prevalence in the country. ${ }^{20}$
In Turkey, inappropriate TM test orders were also impressive: around $90 \%$ of 1858 patients were ordered TM tests in benign conditions. ${ }^{21}$ In Canada, studies showed that the rate of inappropriately ordered tests (not only TMs) could reach 20\%, leading to unnecessary costs of the order of millions of dollars. ${ }^{1,22}$

Table 1. Expenses (in US\$) on appropriate and inappropriate test orders between 2010 and 2017.

\begin{tabular}{l|c|c|c|c|c|c}
\multirow{2}{*}{ Year } & \multicolumn{4}{|c|}{ Appropriate orders } & \multicolumn{3}{c}{ Inappropriate orders } \\
\cline { 2 - 7 } & No. & Insurance cost & Total cost & No. & Insurance cost & Total cost \\
\hline 2010 & 4 & 204.46 & 265.80 & 48 & 2406.32 & 3127.17 \\
\hline 2011 & 4 & 204.46 & 255.59 & 29 & 908.81 & 1136.97 \\
\hline 2013 & 17 & 5040.52 & 5762.00 & 125 & 22597.68 & 25746.49 \\
\hline 2014 & 22 & 5635.15 & 6392.13 & 163 & 21480.95 & 24311.31 \\
\hline 2015 & 29 & 5482.97 & 6180.53 & 185 & 17008.55 & 19425.57 \\
\hline 2016 & 25 & 5078.47 & 5799.02 & 199 & 20672.39 & 23698.56 \\
\hline 2017 & 35 & 6548.59 & 7574.61 & 227 & 22706.55 & 26776.83 \\
\hline TOTAL & 136 & 28194.62 & 32229.69 & 976 & 107781.25 & 124222.91 \\
\hline
\end{tabular}

Table 2. Association between medical specialties and appropriate TM test orders.

\begin{tabular}{|c|c|c|c|c|}
\hline \multirow{2}{*}{ Specialty $^{a}$} & \multirow{2}{*}{ No. of tests } & Appropriate tests & Inappropriate tests & \multirow{2}{*}{ p-value } \\
\hline & & n (\%) & n (\%) & \\
\hline Cardiology & 266 & $19(7.10)$ & 247 (92.90) & 0.000 \\
\hline Internal medicine & 252 & $33(13.10)$ & $219(86.90)$ & 0.000 \\
\hline Obstetrics/gynecology & 213 & $21(9.90)$ & $192(90.10)$ & 0.000 \\
\hline General practice & 179 & $13(7.30)$ & $166(92.70)$ & 0.000 \\
\hline Urology & 88 & $4(4.50)$ & $84(95.50)$ & 0.000 \\
\hline Endocrinology and metabolism & 68 & $5(7.40)$ & $63(92.60)$ & 0.000 \\
\hline Medical oncology & 62 & $47(75.80)$ & $15(24.20)$ & 0.000 \\
\hline General surgery & 51 & $9(17.60)$ & $42(82.40)$ & 0.000 \\
\hline Gastroenterology & 30 & 0 & $30(100)$ & - \\
\hline Infectious disease & 29 & $4(13.80)$ & $25(86.20)$ & 0.000 \\
\hline Breast surgery & 29 & $8(27.60)$ & $21(72.40)$ & 0.01 \\
\hline Gastrointestinal endoscopy & 21 & 0 & $21(100)$ & - \\
\hline Geriatrics & 18 & $2(11.10)$ & $16(88.90)$ & 0.001 \\
\hline Intensive care medicine & 18 & $2(11.10)$ & $16(88.90)$ & 0.001 \\
\hline Dietetics & 18 & 0 & $18(100)$ & - \\
\hline Nephrology & 16 & 0 & $16(100)$ & - \\
\hline Occupational medicine & 15 & $2(13.30)$ & $13(86.70)$ & 0.005 \\
\hline Pediatrics & 14 & $5(35.70)$ & $9(64.30)$ & 0.28 \\
\hline Other specialties ${ }^{\mathrm{b}}$ & 111 & - & - & - \\
\hline
\end{tabular}

aMedical specialty as informed by the respective professional boards: Regional Councils of Medicine of Distrito Federal (CRM-DF), Goiás (CRM-GO), and São Paulo states (CREMESP) in 2018; bmedical specialties that individually accounted for $\leq 1 \%$ : orthopedics and traumatology, neurology, proctology, homeopathy, sports medicine, allergy and immunology, acupuncture, dermatology, hematology and hemotherapy, otolaryngology, oncology, vascular surgery, psychiatry, surgical oncology, gastrointestinal surgery, nuclear medicine, neurosurgery, ophthalmology, pulmonology, rheumatology, health care administration, hospital administration, hepatology, traffic medicine; angiology and vascular surgery, anesthesiology, cardiovascular surgery, head and neck surgery, pathology, peroral endoscopy. 
Regarding medical specialties, we observed that oncologists ordered a larger number of appropriate TM tests compared with other specialists. To the best of our knowledge, to date, no studies have investigated this relationship. Moss et al., evaluating the knowledge of medical professionals regarding the sensitivity and specificity of CA 125 for ovarian cancer, reported that $54 \%$ of general practitioners believed that this marker should not be restricted to disease monitoring, but $40 \%$ of these physicians were unable to identify the causes of false-positive results despite believing they were fit to request this type of test. ${ }^{23}$ In addition, a study by the same authors showed that general practitioners did not feel confident on how to manage patients with a raised CA 125 , even in the presence of a normal ultrasound scan, thus referring these patients for secondary evaluations; this reflects an unfamiliarity of these physicians with the interpretation of TM results. ${ }^{24}$ Considering our results, test orders by oncologists may have had an enhanced sensitivity and consequent appropriateness since these, even when indicated for screening, were based on other diagnostic clues.

Some studies have attempted to explain the reasons that lead physicians to request inappropriate tests, and these reasons include technical unfamiliarity, pressure by the patient and family members, financial gain, and fear of ethical and legal complaints. ${ }^{25,26}$ One study involving 1768 primary care physicians in the United States identified that one-third of them were unfamiliar and uncertain when requesting and interpreting laboratory results for diagnoses in primary care. ${ }^{27}$ It is well known that patients usually ask their doctors for tests and referrals to other specialties. Kravitz et al. reported that 1 in every 5 patients made this type of request. ${ }^{28}$ Moreover, the patient's family influences half of all medical decisions. ${ }^{29}$ It seems that oncologists are less influenced by patients when it comes to requesting procedures and tests. Gogineni et al., studying the demands and requests of patients receiving anticancer treatment, showed that the physician complied with less than $1 \%$ of these demands or requests. ${ }^{30}$

In this context, some studies have proposed strategies and interventions to reduce the number of inappropriately requested tests. ${ }^{25,26}$ Adopting clinical protocols to guide the medical conduct in order to reduce unnecessary or redundant diagnostic tests seems to generate savings of up to $57 \% .^{31} \mathrm{~A}$ study performed within a laboratory of a university hospital in Croatia showed that standardizing minimum intervals for performing tests could lead to a significant reduction (approximately 50\%) in TM test orders, and consequently to a reduction in overall costs. ${ }^{32}$ Similarly, Torre et al. (2015) indicated that the number of adequately requested TMs increased from 31 to $78 \%$ once their utilization protocol was standardized..$^{33}$ Educational programs directed at primary care physicians could lead to a reduction of up to $51 \%$ in performed tests (TMs or not), saving approximately US $\$ 60000$ per year. ${ }^{34}$ In Northern Ireland, researchers showed that $72 \%$ of TM tests were adequately requested, justifying these results by effective audit methods combined with the publication of guidelines..$^{35}$ Physicians believe that evidence-based practice supported by the use of electronic medical records, structured care programs, and continuous quality monitoring and by the identification of barriers and facilitators of clinical practice guidelines are effective strategies to avoid the unnecessary use of tests. ${ }^{36}$

Limitations of this study include its retrospective nature, the fact that only one health insurance and not all its users were included in the sample, and the absence of information from year 2012. Grouping all TMs (CA 125, CEA, CA 15-3, CA 72-4, CA 19-9, and CA 27-29) into one category precluded a more thorough analysis. Nevertheless, the strengths of this study include its large sample size, the period evaluated (7 years), and the quality of the medical records and performed tests, in addition to the fact that this is the first Brazilian study on this topic.

\section{CONCLUSION}

In the present study, performed within a private health insurance over 7 years, we observed a high frequency $(87.80 \%)$ of inappropriate TM test orders. Oncologists were apparently the professionals with the best judgement for ordering these tests. Considering the perspective of a substantial increase in health care costs in the next years, especially in countries such as Brazil, initiatives that aim to reduce the use of unnecessary technologies/tests are of utmost importance. It is possible that audits, physician education programs, well-established protocols, and patient education may contribute to the correct use of these tumor biomarkers.

\section{CONFLICTS OF INTEREST}

The authors do not have any financial or non-financial conflicts of interest.

None.

\section{FUNDING}

\section{AUTHORS' CONTRIBUTION}

EFC: conceptualization, data curation, formal analysis, writing — original draft, writing — review \& editing.

VPNJ: conceptualization, data curation, formal analysis, writing - original draft, writing - review \& editing. 


\section{REFERENCES}

1. Chami N, Simons JE, Sweetman A, Don-Wauchope AC. Rates of inappropriate laboratory test utilization in Ontario. Clin Biochem. 2017;50(15):822-7. https://doi.org/10.1016/j.clinbiochem.2017.05.004

2. Camargos EF. The excessive growth of complementary tests in geriatric practice. Geriatr Gerontol Aging. 2017;11(3):104-6. https:// doi.org/10.5327/Z2447-21152017v11n3ED

3. Zhi M, Ding EL, Theisen-Toupal J, Whelan J, Arnaout R. The landscape of inappropriate laboratory testing: a 15-year meta-analysis. PLoS One. 2013;8(11):e78962. https://doi.org/10.1371/journal. pone.0078962

4. Zhang H, Song Y, Zhang X, Hu J, Yuan S, Ma J. Extent and cost of inappropriate use of tumour markers in patients with pulmonary disease: a multicentre retrospective study in Shanghai, China. BMJ Open. 2018;8(2):e019051. https://doi.org/10.1136/bmjopen-2017-019051

5. Sharma S. Tumor markers in clinical practice: General principles and guidelines. Indian J Med Paediatr Oncol. 2009;30(1):1-8. https://doi. org/10.4103/0971-5851.56328

6. Diamandis EP. Tumor markers: physiology, pathobiology, technology, and clinical applications. Washington, D.C.: AACC Press; 2002.

7. Duffy MJ. Serum tumor markers in breast cancer: are they of clinical value? Clin Chem. 2006;52(3):345-51. https://doi.org/10.1373/ clinchem.2005.059832

8. Zieliniska K, Karczmarek-Borowska B. [Usefulness of the chosen tumor markers at diagnostics and monitoring the treatment]. Przeg Lek. 2013;70(11):986-90.

9. Perkins GL, Slater ED, Sanders GK, Prichard JG. Serum tumor markers. Am Fam Physician. 2003;68(6):1075-82.

10. Ntaios G, Hatzitolios A, Chatzinikolaou A, Karalazou P, Savopoulos C, Karamouzis M, et al. An audit of tumour marker utilization in Greece. Eur J Intern Med. 2009;20(3):e66-69. https://doi.org/10.1016/j. ejim.2008.07.026

11. Force UPST. Screening for Colorectal Cancer: US Preventive Services Task Force Recommendation Statement. JAMA. 2016;315(23):256475. https://doi.org/10.1001/jama.2016.5989

12. Force UPST, Grossman DC, Curry SJ, Owens DK, Barry MJ, Davidson KW, et al. Screening for Ovarian Cancer: US Preventive Services Task Force Recommendation Statement. JAMA. 2018;319(6):588-94. https://doi.org/10.1001/jama.2017.21926

13. Force UPST, Owens DK, Davidson KW, Krist AH, Barry MJ, Cabana $M$, et al. Screening for Pancreatic Cancer: US Preventive Services Task Force Reaffirmation Recommendation Statement. JAMA. 2019;322(5):438-44. https://doi.org/10.1001/jama.2019.10232

14. Royal Australian College of General Practitioners. National Preventive and Community Medicine Committee. Guidelines for preventive activities in general practice. Aust Fam Physician. 2001;Spec No:S1i-xvi, S1-1-61.

15. American Society of Clinical Oncology. Five things physicians and patients should question. J Okla State Med Assoc. 2013;106(2):66-7.

16. Merchán-Hamann E, Tauil PL, Costa MP. Terminologia das medidas e indicadores em epidemiologia: subsídios para uma possível padronização da nomenclatura. Inf Epidemiol SUS. 2000;9(4):27684. http://doi.org/10.5123/S0104-16732000000400006

17. Brasil. Ministério da Saúde. Suplementar ANS. Dados Gerais Beneficiários de planos privados de saúde, por cobertura assistencial (Brasil - 2009-2019). Brasília: Ministério da Saúde; 2020.

18. Arioli D, Pipino M, Boldrini E, Amateis E, Cristani A, Ventura P, et al. Tumour markers in internal medicine: a low-cost test or an unnecessary expense? A retrospective study based on appropriateness. Intern Emerg Med. 2007;2(2):88-94. https://doi.org/10.1007/s11739-007-0028-8

19. Moreno-Campoy EE, Merida-De la Torre FJ, Martos-Crespo F, Plebani M. Identifying risk in the use of tumor markers to improve patient safety. Clin Chem Lab Med. 2016;54(12):1947-53. https:// doi.org/10.1515/cclm-2015-0760
20. Gion M, Peloso L, Trevisiol C, Squarcina E, Zappa M, Fabricio AS. An epidemiology-based model as a tool to monitor the outbreak of inappropriateness in tumor marker requests: a national scale study. Clin Chem Lab Med. 2016;54(3):473-82. https://doi.org/10.1515/ cclm-2015-0329

21. Cure MC, Cure E, Kirbas A, Yazici T, Yuce S. Requests for tumor marker tests in Turkey without indications and frequency of elevation in benign conditions. Asian Pac J Cancer Prev. 2012;13(12):6485-9. https://doi.org/10.7314/apjcp.2012.13.12.6485

22. Morgen EK, Naugler C. Inappropriate repeats of six common tests in a Canadian city: a population cohort study within a laboratory informatics framework. Am J Clin Pathol. 2015;144(5):704-12. https://doi.org/10.1309/ajcpyxdaus2f8xjy

23. Moss EL, Hollingworth J, Holland M, Murphy DJ, Fernando I, Reynolds TM. The use and understanding of CA125 as a tumor marker for ovarian cancer: a questionnaire-based survey. Int J Gynecol Cancer. 2008;18(3):439-45. https://doi.org/10.1111/j.15251438.2007.01043.x

24. Moss EL, Moran A, Reynolds TM, Stokes-Lampard H. Views of general practitioners on the role of CA125 in primary care to diagnose ovarian cancer. BMC Womens Health. 2013;13:8. https:// dx.doi.org/10.1186\%2F1472-6874-13-8

25. Freedman DB. Towards Better Test Utilization - Strategies to Improve Physician Ordering and Their Impact on Patient Outcomes. EJIFCC. 2015;26(1):15-30.

26. Brownlee S, Chalkidou K, Doust J, Elshaug AG, Glasziou P, Heath I, et al. Evidence for overuse of medical services around the world. Lancet. 2017;390(10090):156-68. https://doi.org/10.1016/s01406736(16)32585-5

27. Hickner J, Thompson PJ, Wilkinson T, Epner P, Sheehan M, Pollock AM, et al. Primary care physicians' challenges in ordering clinical laboratory tests and interpreting results. J Am Board Fam Med. 2014;27(2):268-74. https://doi.org/10.3122/jabfm.2014.02.130104

28. Kravitz RL, Bell RA, Azari R, Kelly-Reif S, Krupat E, Thom DH. Direct observation of requests for clinical services in office practice: what do patients want and do they get it? Arch Intern Med. 2003;163(14):167381. https://doi.org/10.1001/archinte.163.14.1673

29. Hobbs GS, Landrum MB, Arora NK, Ganz PA, van Ryn M, Weeks JC, et al. The role of families in decisions regarding cancer treatments. Cancer. 2015;121(7):1079-87. https://doi.org/10.1002\%2Fcncr.29064

30. Gogineni K, Shuman KL, Chinn D, Gabler NB, Emanuel EJ. Patient Demands and Requests for Cancer Tests and Treatments. JAMA Oncol. 2015;1(1):33-9. https://doi.org/10.1001/jamaoncol.2014.197

31. Kosimbei G, Hanson K, English M. Do clinical guidelines reduce clinician dependent costs? Health Res Policy Syst. 2011;9:24. https:// dx.doi.org/10.1186\%2F1478-4505-9-24

32. Lapic I, Rogic D, Fucek M, Galovic R. Effectiveness of minimum retesting intervals in managing repetitive laboratory testing: experience from a Croatian university hospital. Biochem Med (Zagreb). 2019;29(3):030705. https://doi.org/10.11613/bm.2019.030705

33. Torre LA, Bray F, Siegel RL, Ferlay J, Lortet-Tieulent J, Jemal A. Global cancer statistics, 2012. CA Cancer J Clin. 2015;65(2):87-108. https:// doi.org/10.3322/caac.21262

34. Elnenaei MO, Campbell SG, Thoni AJ, Lou A, Crocker BD, Nassar BA. An effective utilization management strategy by dual approach of influencing physician ordering and gate keeping. Clin Biochem. 2016:49(3):208-12. https://doi.org/10.1016/j.clinbiochem.2015.11.005

35. McDonnell M, Northern Ireland Regional Audit G. An audit of tumour marker requests in Northern Ireland. Ann Clin Biochem. 2004;41(Pt 5):378-84. https://doi.org/10.1258/0004563041731655

36. Baynouna Al Ketbi LM, Zein Al Deen S. The attitudes and beliefs of general practitioners towards clinical practice guidelines: a qualitative study in Al Ain, United Arab Emirates. Asia Pac Fam Med. 2018;17:5. https://doi.org/10.1186\%2Fs12930-018-0041-2 